\title{
PENENTUAN PENERIMA BEASISWA DENGAN ALGORITMA FUZZY C-MEANS
}

\author{
Muhardi \\ Teknik Informatika \\ Universitas Megou Pak Tulang Bawang \\ Lampung \\ Jl. Lintas Timur Sumatera Tiuh Tohou Menggala - Tulang Bawang \\ E-mail : ardyardy68@yahoo.co.id
}

\begin{abstract}
ABSTRAK
Beasiswa adalah pemberian berupa bantuan keuangan yang diberikan kepada perorangan yang bertujuan untuk digunakan demi keberlangsungan pendidikan yang ditempuh. Penentuan beasiswa dapat dikelompokan berdasarkan kriteria Indeks Prestasi Kumulatif (IPK), penghasilan orang tua, tanggungan orang tua dan prestasi mahasiswa dalam proses rekruitmen beasiswa.

Algoritma Fuzzy C-Means merupakan satualgoritma yang mudah dan sering digunakan dalam pengelompokan data karena membuat suatu perkiraan yang efisien dan tidak memerlukan banyak parameter.Beberapa penelitian telah menghasilkan kesimpulan bahwa metode Fuzzy C-Means dapat digunakan untuk mengelompokkan data berdasarkan atribut-atributtertentu.

Penerapan algoritma Fuzzy C-Means dalam penentuan beasiswa di kelompokan menjadi tiga cluster yaitu menerima, dipertimbangkan dan tidak berhak menerima beasiswa, sempel data sebenyak 75 data mahasiswa diperoleh tiga cluster berdasarkan nilai rata-rata penentuan beasiswa kemudian setiap cluster diklasifikasikan berdasarkan kriteria mana yang lebih diprioritaskan dengan nilai terbesar pada jarak akhir merupakan cluster yang menerima beasiswa, sedangkan cluster dengan nilai terkecil merupakan cluster yang tidak berhak menerima beasiswa.
\end{abstract}

Kata Kunci : Beasiswa, cluster, Fuzzy C-Means.

\section{ABSTRACT}

Scholarships are gifts in the form of financial assistance given to individuals who aim to be used for the continuity of the education being pursued. Determination of scholarships can be grouped based on the criteria for a Grade Point Average (GPA), income of parents, dependents of parents and student achievements in the scholarship recruitment process.

Fuzzy C-Means algorithm is an easy and often used algorithm in grouping data because it makes an estimate that is efficient and does not require many parameters. Several studies have concluded that the Fuzzy C-Means method can be used to group data based on certain attributes.

The application of Fuzzy C-Means algorithm in determining scholarships is grouped into three clusters namely receiving, being considered and not entitled to receive scholarships, data collection is 75 student data obtained by three clusters based on the average value of scholarship determination then each cluster is classified based on which criteria are prioritized with the largest value at the end of the distance is a cluster that receives scholarships, while the cluster with the smallest value is a cluster that is not entitled to receive scholarships.

Keywords: Scholarship, cluster, Fuzzy C-Means 


\section{PENDAHULUAN}

Beasiswa adalah pemberian berupa bantuan keuangan yang diberikan kepada perorangan yang bertujuan untuk digunakan demi keberlangsungan pendidikan yang ditempuh. Pemberian beasiswa merupakan program kerja yang ada di setiap universitas atau perguruan tinggi. Program beasiswa diadakan untuk meringankan beban mahasiswa dalam menempuh masa studi kuliah khususnya dalam masalah biaya. Pemberian beasiswa kepada mahasiswa dilakukan secara selektif sesuai dengan jenis beasiswa yang diadakan. Univeritas Megow Pak Tulang Bawang menyediakan beberpa program beasiswa, sebagai contoh yaitu beasiswa Peningkatan Akademik (PPA), Beasiswa Bantuan Belajar Mahasiswa (BBM) dan lain sebagainya. Indeks prestasi kumulatif, Tingkat Kemiskinan, tanggungan orang tua dan prestasi menjadi kriteria dalam proses rekruitmen beasiswa.

Proses seleksi penerimaan beasiswa secara manual yaitu dengan menginputkan satu persatu data mahasiswa ke dalam file excel kemudian melakukan sorting data mahasiswa seringkali melakukan beberapa permasalahan, antara lain membutuhkan waktu yang lama dan ketelitian yang tinggi. Selain itu, transparansi serta ketidak jelasan metodologi yang digunakan dalam proses komputasi penerimaan beasiswa juga menjadi salah satu permasalahan, sehingga dibutuhkan suatu sistem yang dapat membantu dalam proses pengambilan keputusan siapa saja mahasiswa yang menerima beasiswa berdasarkan kriteria-kriteria yang telah ditentukan secara capat dan tepat sasaran.

Salah satu metode yang dapat digunakan untuk menyelesaikan permasalahan tersebut adalah metode Fuzzy C-Means. Algoritma Fuzzy C-Means merupakan satu algoritma yang mudah dan sering digunakan dalam pengelompokan data kerana membuat suatu perkiraan yang efsien dan tidak memerlukan banyak parameter. Beberapa penelitian telah menghasilkan kesimpulan bahwa metode Fuzzy CMeans dapat digunakan untuk mengelompokkan data berdasarkan atribut-atribut tertentu. Pada kasus penelitian ini akan menganalisis penerapan metode Fuzzy C-Means untuk mengelompokkan data mahasiswa berdasarkan kemampuan mahasiswa dibidang akademik untuk proses penentuan beasiswa.

Pada penelitian sebelumnya, Bahari (2011) melakukan Penerapan metode Fuzzy C-Means untuk mengelompokan data siswa dalam penentuan jurusan di Sekolah Menengah Atas pada 81 sampel data siswa yang diuji dalam penelitian menunjukan bahwa metode Fuzzy $C$ Means memiliki tingkat akurasi yang lebih tinggi (rata-rata 78,39\%), jika dibandingkan dengan metode penentuan jurusan secara manual yang di lakukan (hanya memiliki tingkat akurasi rata-rata $56,17 \%)$.

Berdasarkan penelitian tersebut, sistem pendukung keputusan penerimaan beasiswa yang akan diimplementasikan dibangun dengan menggunakan metode Fuzzy C-Means. Penelitian ini akan menganalisa penerapan metode Fuzzy Clustering C-Means untuk pengelompokan siapa saja mahasiswa yang menerima beasiswa berdasarkan kriteria-kriteria yang telah ditentukan secara cepat dan tepat sasaran.

\section{TINJAUAN PUSTAKA}

\section{AlgoritmaClustering}

Secara umum pembagian algoritma clustering dapat digambarkan sebagai berikut:

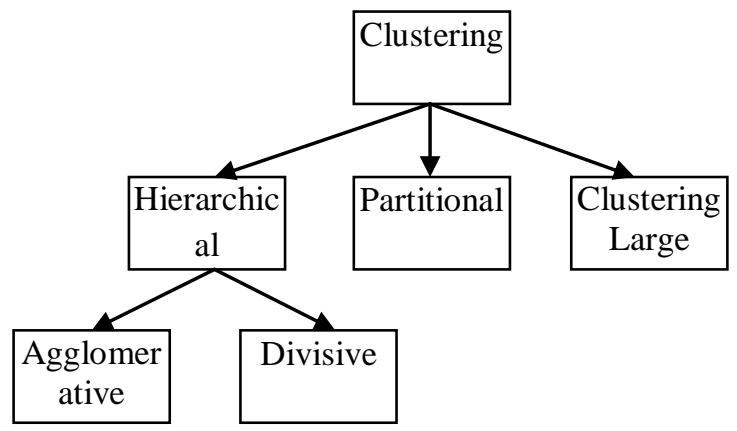

\section{Gambar 1 Kategori Algoritma Clustering}

Hierarchical clustering menentukan sendiri jumlah cluster yang dihasilkan.

Hasil dari metode ini adalah suatu struktur data berbentuk pohon yang disebut dendogram dimana data dikelompokkan secara bertingkat dari yang paling bawah dimana tiap instance data 
merupakan satu cluster sendiri, hingga tingkat paling atas dimana keseluruhan data membentuk satu cluster besar berisi cluster-cluster seperti gambar 2.

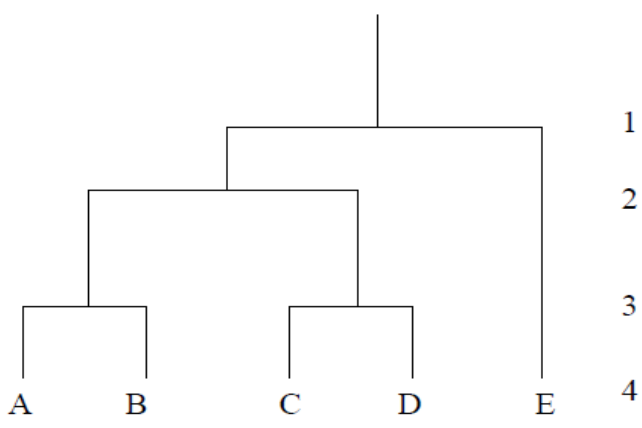

Gambar 2 Dendogram

Divisive hierarchical clustering mengelompokkan data dari kelompok yang terbesar hingga ke kelompok yang terkecil, yaitu masing-masing instance dari kelompok data tersebut. Sebaliknya, agglomerative hierarchical clustering mulai mengelompokkan data dari kelompok yang terkecil hingga kelompok yang terbesar. Beberapa algoritma yang menggunakan metode ini adalah: RObust Clustering Using LinKs (ROCK), Chameleon, Cobweb, Shared Nearest Neighbor (SNN).

Partitional clustering yang mengelompokkan data ke dalam $\mathrm{k}$ cluster dimana $\mathrm{k}$ adalah banyaknya cluster dari input user. Kategori ini biasanya memerlukan pengetahuan yang cukup mendalam tentang data dan proses bisnis yang memanfaatkannya untuk mendapatkan kisaran nilai input yang sesuai. Beberapa algoritma yang masuk dalam kategori ini antara lain: K-Means, Fuzzy C-Means, Clustering Large Aplications (CLARA), Expectation Maximation (EM), Bond Energy Algorithm (BEA), algoritma Genetika, Jaringan Saraf Tiruan.

\section{ALGORITMA FUZZY CLUSTERING C- MEANS (FCM)}

Pada proses pengklasteran (clustering) secara klasik (misalnya pada algoritma Clustering $\mathrm{K}$ Means), pembentukan partisi dilakukan sedemikian rupa sehingga setiap obyek berada tepat pada satu partisi. Namun, adakalanya tidak dapat menempatkan suatu obyek tepat pada suatu partisi, karena sebenarnya obyek tersebut terletak di antara 2 atau lebih partisi yang lain. Pada logika fuzzy, metode yang dapat digunakan untuk melakukan pengelompokan sejumlah data dikenal dengan nama fuzzy clustering. Fuzzy Clustering lebih alami jika dibandingkan dengan pengklasteran secara klasik. Suatu algoritma clustering dikatakan sebagai fuzzy clustering jika algoritma tersebut menggunakan parameter strategi adaptasi secara soft competitive. Sebagian besar algoritma fuzzy clustering didasarkan atas optimasi fungsi obyektif atau modifikasi dari fungsi obyektif tersebut.

Salah satu teknik fuzzy clustering adalah Fuzzy CMeans (FCM). FCM adalah suatu teknik pengklasteran data yang keberadaan tiap-tiap data dalam suatu cluster ditentukan oleh nilai/derajat keanggotaan tertentu. Teknik ini pertama kali diperkenalkan oleh Jim Bezdek pada tahun 1981. Berbeda dengan teknik pengklasteran secara klasik (dimana suatu obyek hanya akan menjadi anggota suatu klaster tertentu), dalam FCM setiap data bisa menjadi anggota dari beberapa cluster.

Batas-batas cluster dalam FCM adalah lunak (soft). Konsep dasar FCM, pertama kali adalah menentukan pusat cluster yang akan menandai lokasi rata-rata untuk tiaptiap cluster. Pada kondisi awal, pusat cluster ini masih belum akurat. Tiaptiap data memiliki derajat keanggotaan untuk tiaptiap cluster. Dengan cara memperbaiki pusat cluster dan nilai keanggotaan tiap-tiap data secara berulang, maa akan terlihat bahwa pusat cluster akan bergerak menuju lokasi yang tepat. Perulangan ini didasarkan pada minimasi fungsi obyektif. Fungsi Obyektif yang digunakan pada FCM adalah:

$$
\begin{aligned}
& \mathrm{J}_{\mathrm{w}}(\mathrm{U}, \mathrm{V} ; \mathrm{X})= \\
& \sum_{k-1}^{n} \sum_{i-=1}^{c}\left(\mu_{i k}\right)^{\mathrm{w}}\left(d_{i k}\right)^{2} .
\end{aligned}
$$

dengan $+\in, 1, \infty)$,

$$
\begin{aligned}
& d_{i k}=d\left(x_{k}-\mathrm{v}_{\mathrm{i}}\right)=\left[\sum _ { j = 1 } ^ { m } \left(x_{k j}-\right.\right. \\
& \left.\left.x_{i j}\right)\right]^{\frac{1}{2}} \ldots \ldots \ldots \ldots \ldots \ldots \ldots \ldots \ldots \ldots \ldots \ldots \ldots \ldots \ldots \ldots \ldots \ldots \ldots
\end{aligned}
$$

$\mathrm{x}$ adalah data yang akan diklaster: 


$$
X=\left[\begin{array}{ccc}
x_{11} & \cdots & x_{1 m} \\
\vdots & & \vdots \\
x_{n 1} & \cdots & x_{n m}
\end{array}\right]
$$

dan $\mathrm{v}$ adalah matriks pusat cluster :

$$
V=\left[\begin{array}{ccc}
v_{11} & \cdots & v_{1 m} \\
\vdots & & \vdots \\
v_{m 1} & \cdots & v_{m m}
\end{array}\right]
$$

nilai Jw terkecil adalah yang terbaik, sehingga:

$$
J_{w}^{*}\left(U^{*}, U^{*} ; x\right)=\min J(U, U ; x) .
$$

Jika $d_{i k}>0, \forall i, k ; w>1$ dan X setidaknya

memiliki m elemen, maka $(u, v) \in$

$M_{f m}>0, \forall i, k ; w$ dapat meminimasi Jw hanya jika:

$$
\mu_{i k}=\frac{\left[\sum_{j=1}^{m}\left(x_{i j}-v_{k j}\right)^{2}\right]^{\frac{-1}{w-1}}}{\sum_{i=1}^{n}\left[\sum_{j=1}^{m}\left(x_{i j}-v_{k j}\right)^{2}\right]^{\frac{-1}{w-1}}}
$$

dan

$v_{k j}=\frac{\sum_{i=1}^{n}\left(\left(\mu_{i k}\right)^{w_{* X}} X_{i j}\right)}{\sum_{i=1}^{n}\left(\mu_{i k}\right)^{w}} ; 1 \leq \mathrm{i} \leq \mathrm{m} ; 1 \leq \mathrm{J} \leq \mathrm{m}$

Algoritma Fuzzy C-Means (FCM) diberikan sebagai berikut :

1. Menentukan data yang akan di cluster $X$, berupa matriks berukuran $\mathrm{n} \quad \mathrm{X} \quad \mathrm{m}$ ( $\mathrm{n}=$ jumlah sampel data, $\mathrm{m}=$ atribut setiap data). Xij=data sampel ke-I $(i=1,2, \ldots, n)$, atribut ke-j $(\mathrm{j}=1,2, \ldots, \mathrm{m})$.

2. Menentukan :

- Jumlah cluster $=\mathrm{c}$

- Pangkat = $\mathrm{W}$

- Maksimum interasi = MaxIter

- Error terkecil yang diharapkan $=\xi$

- Fungsi objektif awal $\quad=\mathrm{P}_{0}=0$

- Interasi awal $\quad=\mathrm{t}=1$

3. Membangkitkan bilangan random $\mu \mathrm{ik}$, $\mathrm{i}=1,2,3 \quad \ldots, \mathrm{n} ; \quad \mathrm{k}=1,2,3 \ldots \mathrm{c} ; \quad$ sebagai elemen-elemen matriks partisi awal U. Menghitung jumlah setiap kolom :

$$
Q_{i}=\sum_{k=1}^{c} \mu_{\mathrm{ik}}
$$

dengan $\mathrm{j}=1,2, \ldots \mathrm{n}$.

Menghitung :

$\mu_{i k}=\frac{\mu_{i k}}{Q_{i}}$

4. Menghitung pusat cluster ke-k: $\mathrm{V}_{\mathrm{kj}}$, dengan $\mathrm{k}=1,2, \ldots \mathrm{c} ;$ dan $\mathrm{j}=1,2, \ldots \mathrm{m}$
$V_{k j}=\frac{\sum_{i=1}^{n}\left(\left(\mu_{i k}\right)^{w_{*}} X_{i j}\right.}{\sum_{i=1}^{n}\left(\left(\mu_{i k}\right)^{w}\right.}$.

5. Menghitung fungsi objektif pada interasi ke$\mathrm{t}$ :

$\mathrm{P}_{\mathrm{t}}=\sum_{i=1}^{n} \sum_{k}^{c}\left(\left[\sum_{j=1}^{m}\left(X_{i j}-V_{k j}\right)^{2}\right]\left(\mu_{i k}\right)^{w}\right) .$.

6. Menghitung perubahan matriks partisi :

$\mu_{i k}=\frac{\left[\sum_{j=1}^{m}\left(X_{i j}-V_{k j}\right)^{2}\right]^{\frac{-1}{w-1}}}{\sum_{k=1}^{c}\left[\sum_{j=1}^{m}\left(X_{i j}-V_{k j}\right)^{2}\right]^{\frac{-1}{w-1}}}$

\section{METODE PENELITIAN}

1 Jenis Penelitian

Penelitian yang dilaksanakan adalah jenis penelitian eksprimen, yaitu melakukan pengujian tingkat akurasi algoritma Fuzzy C-Means clustering sebagai model untuk menentukan penerima beasiswa. Data eksperimen diambil dari tempat penelitian yaitu Universitas Megow Pak Tulang Bawang.

2 Model Pengumpulan Data

Pengumpulan data digunakan untuk mengumpulkan data-data dan informasiinformasi yang diperlukan dalam pembuatan sistem pendukung keputusan. Pengumpulan data pada penelitian ini menggunakan metode pengumpulan data study literature dan telaah dokumen.

\section{PROSES CLUSTERING MENGGUNAKAN FUZZY C-MEANS}

Tahap ini akan diterapkan metode Fuzzy C-Means untuk mengelompokkan data. Hasil pengelompokkan ini kemudian akan digunakan untuk pertimbangan menentukan mahasiswa yang berhak menerima beasiswa. Adapun algoritma $C$ Means Clustering pada penerima beasiswa adalah sebagai berikut :

1. Menetapkan matriks partisi awal $U$ berupa matriks berukuran $\mathrm{n}$ x m (n adalah jumlah sampel data, yaitu=75, dan $m$ adalah parameter/atribut setiap data, yaitu=2). $\mathrm{X}_{\mathrm{ij}}=$ data sampel ke-i $(\mathrm{i}=1,2, \ldots, \mathrm{n})$, atribut ke-j $(\mathrm{j}=1,2, . ., \mathrm{m})$.

2. Menentukan Nilai Parameter Awal :

$\begin{array}{lll}\text { - Jumlah cluster (c) } & =3 \\ \text { - } & \text { Pangkat/bobot (w) } & =2\end{array}$


- $\quad$ Maksimum interasi (MaxIter) $=100$

- $\quad$ Error terkecil yang diharapkan $(\xi)=10^{-5}$

- Fungsi Objektif awal (Po) $\quad=0$

- Interasi awal $(\mathrm{t}) \quad=1$

3. Membangkitkan bilangan random $\mu$ ik, $\mathrm{i}=1,2, \ldots \mathrm{c}$; sebagai elemen-elemen matriks partisi awal (U).

Untuk penelitian ini clustering menggunakan sofware Matlab denga menjalankan di Command Windowyaitu :

$>$ fcm_k3.m

Iteration count $=1$, obj. $\mathrm{fcn}=185.869420$

Iteration count $=2$, obj. $\mathrm{fcn}=146.530736$

Iteration count $=3$, obj. $\mathrm{fcn}=141.726376$

Iteration count $=4$, obj. $\mathrm{fcn}=134.833704$

Iteration count $=5$, obj. $\mathrm{fcn}=130.961108$

Iteration count $=6$, obj. $\mathrm{fcn}=129.145894$

Iteration count $=7$, obj. $\mathrm{fcn}=127.219322$

Iteration count $=8$, obj. fcn $=124.903487$

Iteration count $=9$, obj. $\mathrm{fcn}=122.880711$

Iteration count $=10$, obj. $\mathrm{fcn}=121.359551$

Iteration count $=11$, obj. $\mathrm{fcn}=119.898753$

Iteration count $=12$, obj. $\mathrm{fcn}=118.236843$

Iteration count $=13$, obj. $\mathrm{fcn}=116.491898$

Iteration count $=14$, obj. fcn $=114.963865$

Iteration count $=15$, obj. $\mathrm{fcn}=113.865257$

Iteration count $=16$, obj. $\mathrm{fcn}=113.180881$

Iteration count $=17$, obj. fcn $=112.770379$

Iteration count $=18$, obj. $\mathrm{fcn}=112.513345$

Iteration count $=19$, obj. $\mathrm{fcn}=112.342297$

Iteration count $=20$, obj. $\mathrm{fcn}=112.223512$

Iteration count $=21$, obj. $\mathrm{fcn}=112.139405$

Iteration count $=22$, obj. $\mathrm{fcn}=112.079712$

Iteration count $=23$, obj. $\mathrm{fcn}=112.037682$

Iteration count $=24$, obj. fcn $=112.008476$

Iteration count $=25$, obj. $\mathrm{fcn}=111.988487$

Iteration count $=26$, obj. $\mathrm{fcn}=111.975011$

Iteration count $=27$, obj. $\mathrm{fcn}=111.966053$

Iteration count $=28$, obj. $\mathrm{fcn}=111.960170$

Iteration count $=29$, obj. $\mathrm{fcn}=111.956348$

Iteration count $=30$, obj. $\mathrm{fcn}=111.953887$

Iteration count $=31$, obj. $\mathrm{fcn}=111.952314$

Iteration count $=32$, obj. $\mathrm{fcn}=111.951315$

Iteration count $=33$, obj. $\mathrm{fcn}=111.950683$

Iteration count $=34$, obj. $\mathrm{fcn}=111.950285$

Iteration count $=35$, obj. $\mathrm{fcn}=111.950035$
Iteration count $=36$, obj. $\mathrm{fcn}=111.949879$

Iteration count $=37$, obj. $\mathrm{fcn}=111.949781$

$\mathrm{C}=$

$\begin{array}{llll}3.2649 & 1.8625 & 2.2484 & 4.2701 \\ 3.1653 & 1.6271 & 5.1550 & 1.1770 \\ 3.2225 & 2.4133 & 3.0759 & 0.7967\end{array}$

\section{HASIL DAN PEMBAHASAN}

Penyebaran masing-masing anggota cluster pada iterasi terakhir dapt dilihat pada cluster interface gambar dibawah ini :

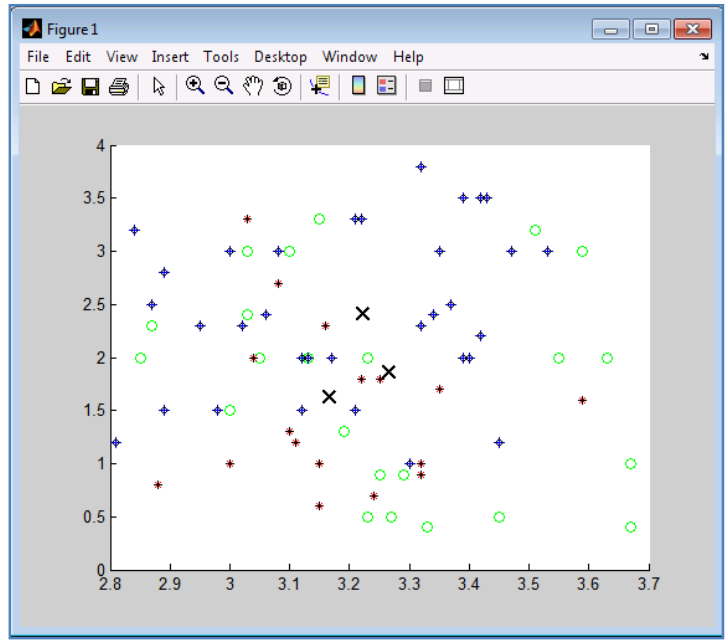

Keterangan :

Tanda ${ }^{*}=$ cluster 1

Tanda $\$$ = cluster 2

Tanda $=$ cluster 3

Tanda $\mathrm{X}=$ pusat ke 3 cluster

Detail Matriks partisi U yang dihasilkan pada iterasi terakhir (iterasi ke-37) menggunakan fungsi Matlab adalah :

Columns 1 through 10

\begin{tabular}{lccccc}
0.1634 & 0.5724 & \multicolumn{4}{c}{0.05230 .04670 .91980 .0643} \\
0.0525 & 0.1063 & 0.0438 & 0.0605 & \\
0.1810 & 0.1653 & 0.0954 & 0.3021 & 0.0345 \\
0.7542 & 0.2756 & 0.1726 & 0.3300 & 0.1892 \\
0.6557 & 0.2623 & 0.8522 & 0.6512 & 0.0457 \\
0.1815 & 0.6719 & 0.7211 & 0.6262 & 0.7503
\end{tabular}

Columns 11 through 20

$\begin{array}{lccccc}0.0507 & 0.0576 & 0.6670 & 0.0923 & 0.6497 \\ 0.1132 & 0.6893 & 0.0108 & 0.7094 & 0.0427 \\ 0.7378 & 0.2660 & 0.1091 & 0.0971 & 0.1801 \\ 0.6406 & 0.1642 & 0.9393 & 0.0919 & 0.3048\end{array}$


$\begin{array}{lllll}0.2115 & 0.6763 & 0.2239 & 0.8107 & 0.1701\end{array}$

$\begin{array}{llllll}0.2463 & 0.1465 & 0.0500 & 0.1987 & 0.6525\end{array}$

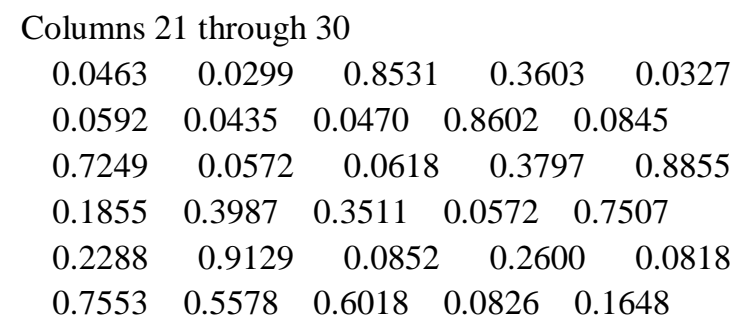

Columns 31 through 40

$$
\begin{array}{lccccc}
0.8104 & 0.0560 & 0.1747 & 0.0183 & 0.3397 \\
0.6931 & 0.0611 & 0.0556 & 0.2106 & 0.6219 \\
0.0792 & 0.8198 & 0.6184 & 0.0430 & 0.3074 \\
0.1693 & 0.1484 & 0.1314 & 0.5727 & 0.1510 \\
0.1105 & 0.1242 & 0.2069 & 0.9386 & 0.3530 \\
0.1376 & 0.7904 & 0.8130 & 0.2167 & 0.2271
\end{array}
$$

Columns 41 through 50

$$
\begin{array}{lccccc}
0.0513 & 0.1739 & 0.5558 & 0.8307 & 0.8829 \\
0.1085 & 0.0982 & 0.0307 & 0.0732 & 0.0897 \\
0.8324 & 0.6221 & 0.2029 & 0.0788 & 0.0535 \\
0.2561 & 0.1566 & 0.0896 & 0.4973 & 0.0934 \\
0.1163 & 0.2040 & 0.2413 & 0.0905 & 0.0636 \\
0.6354 & 0.7452 & 0.8797 & 0.4295 & 0.8170
\end{array}
$$

Columns 51 through 60

$$
\begin{array}{lccccc}
0.0050 & 0.1026 & 0.0297 & 0.0466 & 0.0378 \\
0.0673 & 0.0446 & 0.0707 & 0.5855 & 0.5157 \\
0.9734 & 0.1039 & 0.0565 & 0.2871 & 0.1144 \\
0.1508 & 0.3947 & 0.5757 & 0.1587 & 0.2346 \\
0.0216 & 0.7934 & 0.9139 & 0.6663 & 0.8478 \\
0.7819 & 0.5607 & 0.3536 & 0.2558 & 0.2497
\end{array}
$$

$$
\begin{array}{cccccc}
\text { Columns } 61 \text { through } 70 & & & \\
0.0825 & 0.0826 & 0.0433 & 0.1208 & 0.6158 \\
0.0877 & 0.1063 & 0.7764 & 0.0346 & 0.8865 \\
0.2752 & 0.2753 & 0.3423 & 0.1954 & 0.1421 \\
0.1292 & 0.1073 & 0.0887 & 0.0653 & 0.0543 \\
0.6423 & 0.6421 & 0.6144 & 0.6838 & 0.2421 \\
0.7831 & 0.7864 & 0.1349 & 0.9000 & 0.0592
\end{array}
$$

$\begin{array}{ccccc}\text { Columns } 71 \text { through } 75 \\ 0.8488 & 0.0548 & 0.7033 & 0.6666 & 0.7703 \\ 0.0635 & 0.4938 & 0.0943 & 0.1236 & 0.1006 \\ 0.0877 & 0.4514 & 0.2024 & 0.2097 & 0.1291\end{array}$

Dari matriks partisi U tersebut dapat diperoleh informasi mengenai kecenderungan suatu penerima beasiswa untuk masuk ke kelompok ( cluster) yang mana. Suatu penerima beasiswa memiliki derajat keanggotaan tertentu unutk menjadi anggota suatu kelompok. Tentu saja derajat keanggotaan tersebar menunjukkan kecenderungan tertinggi suatu penerima biasiswa untuk masuk menjadi anggota kelompok.

Pada iterasi terakhir (iterasi ke-37), pusat cluster Vkj yang dihasilkan dengan $k=1,2,3,4$ dan $j=1,2$ adalah:

$V k j=\left(\begin{array}{llll}3.2649 & 1.8625 & 2.2484 & 4.2701 \\ 3.1653 & 1.6271 & 5.1550 & 1.1770 \\ 3.2225 & 2.4133 & 3.0759 & 0.7967\end{array}\right)$

Nilai ini merupakan nilai dari koordinat ketiga titik pusat cluster dan memberikan garis besar tiap cluster yaitu:

1. Kelompok pertama (cluster ke-1), berisi data mahasiswa yang memiliki rata-rata ipk sekitar 3.2649; memiliki rata-rata penghasilan orang tua sekitar 1.8625; tanggungan orang tua 2.2484 dan memiliki prestasi 4.2701 .

2. Kelompok kedua (cluster ke-2), berisi data mahasiswa yang memiliki rata-rata ipk sekitar 3.1653; memiliki rata-rata penghasilan orang tua sekitar 1.6271; tanggungan orang tua 5.1550 dan memiliki prestasi 1.1770 .

3. Kelompok ketiga (cluster ke-3), berisi data mahasiswa yang memiliki rata-rata ipk sekitar 3.2225; memiliki rata-rata penghasilan orang tua sekitar 2.4133; tanggungan orang tua 3.0759 dan memiliki prestasi 0.7967 .

Derajat keanggotaan penentuan beasiswa untuk sertiap cluster pada iterasi terakhir (iterasi ke-37) dapat dilihat pada Tabel 4.2 di bawah ini:

Tabel 1. Derajat Keanggotaan Penentuan Beasiswa Untuk Setiap Cluster Pada Iterasi Terakhir 


\begin{tabular}{|c|c|c|c|c|c|c|}
\hline \multirow[t]{2}{*}{ No } & \multicolumn{3}{|c|}{$\begin{array}{c}\text { Derajat Keanggotaan }(\mu) \\
\text { pada Iterasi Terakhir }\end{array}$} & \multicolumn{3}{|c|}{$\begin{array}{c}\text { Kecenderungan } \\
\text { data masuk pada } \\
\text { cluster }\end{array}$} \\
\hline & $\left(\mu_{1}\right)$ & $\left(\mu_{2}\right)$ & $\left(\mu_{3}\right)$ & $\mathrm{C} 1$ & $\mathrm{C} 2$ & C3 \\
\hline 1 & 0.1634 & 0.1810 & 0.6557 & & & $*$ \\
\hline 2 & 0.5724 & 0.1653 & 0.2623 & $*$ & & \\
\hline 3 & 0.0523 & 0.0954 & 0.8522 & & & $*$ \\
\hline 4 & 0.0467 & 0.3021 & 0.6512 & & & $*$ \\
\hline 5 & 0.9198 & 0.0345 & 0.0457 & $*$ & & \\
\hline 6 & 0.0643 & 0.7542 & 0.1815 & & $*$ & \\
\hline 7 & 0.0525 & 0.2756 & 0.6719 & & & $*$ \\
\hline 8 & 0.1063 & 0.1726 & 0.7211 & & & $*$ \\
\hline 9 & 0.0438 & 0.3300 & 0.6262 & & & $*$ \\
\hline 10 & 0.0605 & 0.1892 & 0.7503 & & & $*$ \\
\hline 11 & 0.0507 & 0.7378 & 0.2115 & & $*$ & \\
\hline 12 & 0.0576 & 0.2660 & 0.6763 & & & $*$ \\
\hline 13 & 0.6670 & 0.1091 & 0.2239 & $*$ & & \\
\hline 14 & 0.0923 & 0.0971 & 0.8107 & & & $*$ \\
\hline 15 & 0.6497 & 0.1801 & 0.1701 & $*$ & & \\
\hline 16 & 0.1132 & 0.6406 & 0.2463 & & $*$ & \\
\hline 17 & 0.6893 & 0.1642 & 0.1465 & $*$ & & \\
\hline 18 & 0.0108 & 0.9393 & 0.0500 & & $*$ & \\
\hline 19 & 0.7094 & 0.0919 & 0.1987 & $*$ & & \\
\hline 20 & 0.0427 & 0.3048 & 0.6525 & & & $*$ \\
\hline 21 & 0.0463 & 0.7249 & 0.2288 & & $*$ & \\
\hline 22 & 0.0299 & 0.0572 & 0.9129 & & & $*$ \\
\hline 23 & 0.8531 & 0.0618 & 0.0852 & $*$ & & \\
\hline 24 & 0.3603 & 0.3797 & 0.2600 & & $*$ & \\
\hline 25 & 0.0327 & 0.8855 & 0.0818 & & $*$ & \\
\hline 26 & 0.0592 & 0.1855 & 0.7553 & & & $*$ \\
\hline 27 & 0.0435 & 0.3987 & 0.5578 & & & $*$ \\
\hline 28 & 0.0470 & 0.3511 & 0.6018 & & & $*$ \\
\hline 29 & 0.8602 & 0.0572 & 0.0826 & $*$ & & \\
\hline 30 & 0.0845 & 0.7507 & 0.1648 & & $*$ & \\
\hline 31 & 0.8104 & 0.0792 & 0.1105 & $*$ & & \\
\hline 32 & 0.0560 & 0.8198 & 0.1242 & & $*$ & \\
\hline 33 & 0.1747 & 0.6184 & 0.2069 & & $*$ & \\
\hline 34 & 0.0183 & 0.0430 & 0.9386 & & & $*$ \\
\hline 35 & 0.3397 & 0.3074 & 0.3530 & & & $*$ \\
\hline 36 & 0.6931 & 0.1693 & 0.1376 & $*$ & & \\
\hline 37 & 0.0611 & 0.1484 & 0.7904 & & & $*$ \\
\hline 38 & 0.0556 & 0.1314 & 0.8130 & & & $*$ \\
\hline 39 & 0.2106 & 0.5727 & 0.2167 & & $*$ & \\
\hline 40 & 0.6219 & 0.1510 & 0.2271 & $*$ & & \\
\hline 41 & 0.0513 & 0.8324 & 0.1163 & & $*$ & \\
\hline 42 & 0.1739 & 0.6221 & 0.2040 & & $*$ & \\
\hline
\end{tabular}

\begin{tabular}{|c|c|c|c|c|c|c|}
\hline 43 & 0.5558 & 0.2029 & 0.2413 & $*$ & & \\
\hline 44 & 0.8307 & 0.0788 & 0.0905 & $*$ & & \\
\hline 45 & 0.8829 & 0.0535 & 0.0636 & $*$ & & \\
\hline 46 & 0.1085 & 0.2561 & 0.6354 & & & $*$ \\
\hline 47 & 0.0982 & 0.1566 & 0.7452 & & & $*$ \\
\hline 48 & 0.0307 & 0.0896 & 0.8797 & & & $*$ \\
\hline 49 & 0.0732 & 0.4973 & 0.4295 & & $*$ & \\
\hline 50 & 0.0897 & 0.0934 & 0.8170 & & & $*$ \\
\hline 51 & 0.0050 & 0.9734 & 0.0216 & & $*$ & \\
\hline 52 & 0.1026 & 0.1039 & 0.7934 & & & $*$ \\
\hline 53 & 0.0297 & 0.0565 & 0.9139 & & & $*$ \\
\hline 54 & 0.0466 & 0.2871 & 0.6663 & & & $*$ \\
\hline 55 & 0.0378 & 0.1144 & 0.8478 & & & $*$ \\
\hline 56 & 0.0673 & 0.1508 & 0.7819 & & & $*$ \\
\hline 57 & 0.0446 & 0.3947 & 0.5607 & & & $*$ \\
\hline 58 & 0.0707 & 0.5757 & 0.3536 & & $*$ & \\
\hline 59 & 0.5855 & 0.1587 & 0.2558 & $*$ & & \\
\hline 60 & 0.5157 & 0.2346 & 0.2497 & $*$ & & \\
\hline 61 & 0.0825 & 0.2752 & 0.6423 & & & $*$ \\
\hline 62 & 0.0826 & 0.2753 & 0.6421 & & & $*$ \\
\hline 63 & 0.0433 & 0.3423 & 0.6144 & & & $*$ \\
\hline 64 & 0.1208 & 0.1954 & 0.6838 & & & $*$ \\
\hline 65 & 0.6158 & 0.1421 & 0.2421 & $*$ & & \\
\hline 66 & 0.0877 & 0.1292 & 0.7831 & & & $*$ \\
\hline 67 & 0.1063 & 0.1073 & 0.7864 & & & $*$ \\
\hline 68 & 0.7764 & 0.0887 & 0.1349 & $*$ & & \\
\hline 69 & 0.0346 & 0.0653 & 0.9000 & & & $*$ \\
\hline 70 & 0.8865 & 0.0543 & 0.0592 & $*$ & & \\
\hline 71 & 0.8488 & 0.0635 & 0.0877 & $*$ & & \\
\hline 72 & 0.0548 & 0.4938 & 0.4514 & & $*$ & \\
\hline 73 & 0.7033 & 0.0943 & 0.2024 & $*$ & & \\
\hline 74 & 0.6666 & 0.1236 & 0.2097 & $*$ & & \\
\hline 75 & 0.7703 & 0.1006 & 0.1291 & $*$ & & \\
\hline
\end{tabular}

Dari table 1 dapat di simpulkan bahwa :

1. Kelompok pertama (cluster ke-1), akan berisi data mahasiswa ke :2, 5, 13, 15, 17, 19, 23, $29,31,36,40,43,44,45,59,60,65,68,70$, 71, 73, 74 dan 75.

2. Kelompok kedua (cluster ke-2), akan berisi data mahasiswake :6, 11, 16, 18, 21, 24, 25, 30, 32, 33, 39, 41, 42, 49, 51, 58 dan72.

3. Kelompok ketiga (cluster ke-3), akan berisi data mahasiswake : $1,3,4,7,8,9,10,12$, $14,20,22,26,27,28,34,35,37,38,46,47$, $48,50,52,53,54,55, \quad 56,57,61,62,63$, 64, 66, 67 dan69. 
Proses Clustering memerlukan klasifikasi untuk menentukan kelompok (cluster) mana yang berhak untuk menerima beasiswa. Dalam penelitian akan mengelompokkan mahasiswa mejadi tiga (3) clusteryaitu :

1. Cluster yang menerima beasiswa

2. Cluster yang dipertimbangkan menerima beasiswa.

3. Cluster yang tidak menerima beasiswa.

Kemudian setiap cluster dibagi berdasarkan kriteria mana yang lebih diprioritaskan (berdasarkan IPK atau PO (Penghasilan Orang tua), Tangguangan Orang Tua (TO), Prestasi mahasiswa selama menjadi mahasiswa).

Iterasi pada percobaan ini berhenti pada iterasi ke37. Hasil akhir clutering yang di perolah adalah :

1. Cluster pertama memiliki pusat cluster (3.2649; 1.8625; 2.2484; 4.2701)

2. Cluster kedua memiliki pusat cluster (3.1653; 1.6271; 5.1550; 1.1770)

3. Cluster ketiga memiliki pusat cluster (3.2225; 2.4133; 3.0759; 0.7967)

Hasil klasifikasi clustering dapat dilihat pada Tabel 2

Tabel 2 Hasil Kalasifikasi

\begin{tabular}{|c|c|c|}
\hline \multicolumn{3}{|c|}{ Proritas IPK } \\
\hline Menerima & Dipertimbangkan & $\begin{array}{c}\text { Tidak } \\
\text { Menerima }\end{array}$ \\
\hline Cluster 1 & Cluster 3 & Cluster 2 \\
\hline 3.2649 & 3.2225 & 3.1653 \\
\hline \multicolumn{3}{|c|}{ Prioritas TK } \\
\hline Menerima & Dipertimbangkan & $\begin{array}{c}\text { Tidak } \\
\text { Menerima }\end{array}$ \\
\hline Cluster 3 & Cluster 1 & Cluster 2 \\
\hline 2.4133 & 1.8625 & 1.6271 \\
\hline \multicolumn{3}{|c|}{ Prioritas TO } \\
\hline Menerima & Dipertimbangkan & $\begin{array}{c}\text { Tidak } \\
\text { Menerima }\end{array}$ \\
\hline Cluster 2 & Cluster 3 & Cluster 1 \\
\hline 5.1550 & 3.0759 & 2.2484 \\
\hline \multicolumn{3}{|c|}{ Prioritas Prestasi } \\
\hline Menerima & Dipertimbangkan & $\begin{array}{c}\text { Tidak } \\
\text { Menerima }\end{array}$ \\
\hline Cluster 1 & Cluster 2 & Cluster 3 \\
\hline
\end{tabular}

\begin{tabular}{|l|l|l|}
\hline 4.2701 & 1.1770 & 0.7967 \\
\hline
\end{tabular}

Tabel 3 Hasil klasifikasi prioritas mahasiswa

\begin{tabular}{|c|c|c|c|c|c|c|c|c|c|}
\hline No & IPK & PO & TO & $\begin{array}{c}\text { Prest } \\
\text { asi }\end{array}$ & $C$ & IPK & PO & TO & $\begin{array}{c}\text { Prest } \\
\text { asi }\end{array}$ \\
\hline 1 & 2.81 & 1.2 & 2 & 1 & 3 & DP & DP & $\mathrm{M}$ & TM \\
\hline 2 & 2.85 & 2 & 3 & 3 & 1 & $\mathrm{M}$ & $\mathrm{TM}$ & DP & $\mathrm{M}$ \\
\hline 3 & 2.84 & 3.2 & 3 & 1 & 3 & DP & DP & $\mathrm{M}$ & TM \\
\hline 4 & 2.87 & 2.5 & 4 & 1 & 3 & DP & DP & $\mathrm{M}$ & TM \\
\hline 5 & 2.87 & 2.3 & 2 & 5 & 1 & $\mathrm{M}$ & TM & DP & $\mathrm{M}$ \\
\hline 6 & 2.88 & 0.8 & 6 & 0 & 2 & $\mathrm{TM}$ & $\mathrm{M}$ & $\mathrm{TM}$ & DP \\
\hline 7 & 2.89 & 2.8 & 4 & 1 & 3 & DP & DP & $\mathrm{M}$ & TM \\
\hline 8 & 2.89 & 1.5 & 2 & 0 & 3 & DP & DP & $\mathrm{M}$ & TM \\
\hline 9 & 2.95 & 2.3 & 4 & 1 & 3 & DP & DP & M & $\mathrm{TM}$ \\
\hline 10 & 2.98 & 1.5 & 3 & 0 & 3 & DP & DP & $\mathrm{M}$ & TM \\
\hline 11 & 3 & 1 & 5 & 0 & 2 & TM & $\mathrm{M}$ & TM & DP \\
\hline 12 & 3 & 3 & 4 & 1 & 3 & DP & DP & $\mathrm{M}$ & TM \\
\hline 13 & 3 & 1.5 & 1 & 3 & 1 & $\mathrm{M}$ & $\mathrm{TM}$ & DP & $\mathrm{M}$ \\
\hline 14 & 3.02 & 2.3 & 2 & 1 & 3 & DP & DP & $\mathrm{M}$ & TM \\
\hline 15 & 3.03 & 3 & 4 & 5 & 3 & DP & DP & $\mathrm{M}$ & TM \\
\hline 16 & 3.03 & 3.3 & 7 & 1 & 2 & TM & $\mathrm{M}$ & TM & DP \\
\hline 17 & 3.03 & 2.4 & 4 & 5 & 1 & $\mathrm{M}$ & $\mathrm{TM}$ & DP & $\mathrm{M}$ \\
\hline 18 & 3.04 & 2 & 5 & 1 & 2 & TM & M & TM & DP \\
\hline 19 & 3.05 & 2 & 2 & 3 & 1 & $\mathrm{M}$ & $\mathrm{TM}$ & DP & $\mathrm{M}$ \\
\hline 20 & 3.06 & 2.4 & 4 & 1 & 3 & DP & DP & $\mathrm{M}$ & TM \\
\hline 21 & 3.08 & 2.7 & 5 & 1 & 2 & TM & $\mathrm{M}$ & TM & DP \\
\hline 22 & 3.08 & 3 & 3 & 1 & 3 & DP & $\mathrm{DP}$ & $\mathrm{M}$ & TM \\
\hline 23 & 3.1 & 3 & 2 & 5 & 1 & $\mathrm{M}$ & TM & DP & $\bar{M}$ \\
\hline 24 & 3.1 & 1.3 & 4 & 3 & 2 & TM & $\mathrm{M}$ & TM & DP \\
\hline 25 & 3.11 & 1.2 & 6 & 1 & 2 & TM & $\mathrm{M}$ & TM & DP \\
\hline 26 & 3.12 & 1.5 & 3 & 0 & 3 & DP & DP & $\mathrm{M}$ & TM \\
\hline 27 & 3.12 & 2 & 4 & 1 & 3 & DP & DP & $\mathrm{M}$ & TM \\
\hline 28 & 3.13 & 2 & 4 & 0 & 1 & $\mathrm{M}$ & TM & DP & M \\
\hline 29 & 3.13 & 2 & 1 & 5 & 2 & TM & $\mathrm{M}$ & TM & DP \\
\hline 30 & 3.15 & 1 & 7 & 1 & 2 & TM & $\mathrm{M}$ & TM & DP \\
\hline 31 & 3.15 & 3.3 & 2 & 5 & 1 & $\mathrm{M}$ & TM & DP & $\mathrm{M}$ \\
\hline 32 & 3.15 & 0.6 & 6 & 1 & 2 & TM & $\mathrm{M}$ & TM & DP \\
\hline 33 & 3.16 & 2.3 & 6 & 3 & 2 & TM & M & TM & DP \\
\hline 34 & 3.17 & 2 & 3 & 1 & 3 & DP & DP & $\mathrm{M}$ & TM \\
\hline 35 & 3.22 & 3.3 & 4 & 3 & 3 & DP & DP & $\mathrm{M}$ & TM \\
\hline 36 & 3.19 & 1.3 & 4 & 5 & 1 & $\mathrm{M}$ & $\mathrm{TM}$ & DP & $\mathrm{M}$ \\
\hline 37 & 3.21 & 1.5 & 3 & 1 & 3 & DP & DP & $\mathrm{M}$ & $\mathrm{TM}$ \\
\hline 38 & 3.21 & 3.3 & 3 & 0 & 3 & DP & DP & $\mathrm{M}$ & $\mathrm{TM}$ \\
\hline 39 & 3.22 & 1.8 & 5 & 3 & 2 & TM & $\mathrm{M}$ & TM & DP \\
\hline 40 & 3.23 & 0.5 & 2 & 3 & 1 & $M$ & $\mathrm{TM}$ & DP & $\mathrm{M}$ \\
\hline 41 & 3.24 & 0.7 & 6 & 1 & 2 & TM & $\mathrm{M}$ & TM & DP \\
\hline
\end{tabular}




\begin{tabular}{|c|c|c|c|c|c|c|c|c|c|}
\hline 42 & 3.25 & 1.8 & 7 & 3 & 2 & TM & M & TM & DP \\
\hline 43 & 3.25 & 0.9 & 3 & 3 & 1 & M & TM & DP & M \\
\hline 44 & 3.27 & 0.5 & 2 & 5 & 1 & M & TM & DP & M \\
\hline 45 & 3.29 & 0.9 & 2 & 5 & 1 & M & TM & DP & M \\
\hline 46 & 3.3 & 1 & 3 & 1 & 3 & DP & DP & M & TM \\
\hline 47 & 3.32 & 3.8 & 3 & 1 & 3 & DP & DP & M & TM \\
\hline 48 & 3.32 & 2.3 & 3 & 0 & 3 & DP & DP & M & TM \\
\hline 49 & 3.32 & 0.9 & 4 & 0 & 2 & TM & M & TM & DP \\
\hline 50 & 3.34 & 2.4 & 2 & 1 & 3 & DP & DP & M & TM \\
\hline 51 & 3.35 & 1.7 & 5 & 1 & 2 & TM & M & TM & DP \\
\hline 52 & 3.35 & 3 & 2 & 1 & 3 & DP & DP & M & TM \\
\hline 53 & 3.35 & 3 & 3 & 1 & 3 & DP & DP & M & TM \\
\hline 54 & 3.37 & 2.5 & 4 & 0 & 3 & DP & DP & M & TM \\
\hline 55 & 3.39 & 2 & 3 & 0 & 3 & DP & DP & M & TM \\
\hline 56 & 3.39 & 3.5 & 3 & 0 & 3 & DP & DP & M & TM \\
\hline 57 & 3.4 & 2 & 4 & 1 & 3 & DP & DP & M & TM \\
\hline 58 & 3.32 & 1 & 4 & 1 & 2 & TM & M & TM & DP \\
\hline 59 & 3.23 & 2 & 3 & 3 & 2 & TM & M & TM & DP \\
\hline 60 & 3.33 & 0.4 & 3 & 3 & 1 & M & TM & DP & M \\
\hline 61 & 3.42 & 3.5 & 4 & 1 & 3 & DP & DP & M & TM \\
\hline 62 & 3.43 & 3.5 & 4 & 1 & 3 & DP & DP & M & TM \\
\hline 63 & 3.42 & 2.2 & 4 & 1 & 3 & DP & DP & M & TM \\
\hline 64 & 3.45 & 1.2 & 2 & 0 & 3 & DP & DP & M & TM \\
\hline 65 & 3.45 & 0.5 & 1 & 3 & 1 & M & TM & DP & M \\
\hline 66 & 3.47 & 3 & 2 & 0 & 3 & DP & DP & M & TM \\
\hline 67 & 3.53 & 3 & 2 & 1 & 3 & DP & DP & M & TM \\
\hline 68 & 3.51 & 3.2 & 1 & 5 & 1 & M & TM & DP & M \\
\hline 69 & 3.53 & 3 & 3 & 1 & 3 & DP & DP & M & TM \\
\hline 70 & 3.55 & 2 & 3 & 5 & 1 & M & TM & DP & M \\
\hline 71 & 3.59 & 3 & 2 & 5 & 1 & M & TM & DP & M \\
\hline 72 & 3.59 & 1.6 & 4 & 1 & 2 & TM & M & TM & DP \\
\hline 73 & 3.63 & 2 & 2 & 3 & 1 & M & TM & DP & M \\
\hline 74 & 3.67 & 1 & 2 & 3 & 1 & M & TM & DP & M \\
\hline 75 & 3.67 & 0.4 & 1 & 5 & 1 & M & TM & DP & M \\
\hline
\end{tabular}

Berdasarkan pembahasan maka dapat diberikan beberapakan simpulan sebagai berikut :

1. Dari data yang dilatih, diperoleh tiga kelompk berdasarkan nilai rata-rata penentuan beasiswa, yaitu :

- Kelompk pertama (cluster ke-1), berisi mahasiswa yang memiliki rata-rata ipk sekitar 3.2649; memiliki rata-rata tingkat kemiskinan sekitar 1.8625; tanggungan orang tua 2.2484 dan memiliki prestasi 4.2701.

- Kelompok kedua (cluster ke-2), berisi mahasiswa yang memiliki rata-rata ipk sekitar 3.1653; memiliki rata-rata tingkat kemiskinan sekitar 1.6271; tanggunan orang tua 5.1550 dan memiliki prestasi 1.1770 .

- Kelompok ketiga (caluser ke-3), berisi mahasiswa yang memiliki rata-rata ipk sekitar 3.2225; memiliki prestasi 0.7967

2. Pada saat dilakukan proses dikelompokkan menjadi tiga cluster (menerima, dipertimbangkan dan tidak berhak menerima). Kemudian stiap cluster diklasifikasikan berdasarkan kriteria mana yang lebih diprioritaskan yaitu salah satu dari kriteria IPK, tingkat kemsikinan, Tanggungan Orang tua dan Prestasi. Cluster dengan nilai terbesar pada pusat cluster $V k j$ terakhir merupakan cluster yang direkomendasikan menerima beasiswa, sedangkan cluster dengan nilai terkecil merupakan cluster yang tidak berhak menerima beasiswa.

\section{DAFTAR PUSTAKA}

Keterangan :

M : menerima.

DP : dipertimbangkan.

TM : tidak menerima.

Berdasarkan tabel prioritas di atas terdapat 3 cluster yaitu menerima, dipertimbangkan dan tidak menerima yang di hasilkan dari tabel kalsifikasi.

[1] Bahari, 2011 Penentuan Jurusan sekolah Mengah Atas Dengan Algoritam Fuzzy C-Means, Proceeding Pada Program Pasca sarjana Magister Teknik Informatika Universitas Dian Nuswantoro semarang, Jurusan Sistem Informasi, Universitas Dian Nuswontoro Semarang.

[2] Emha Taufiq Luthfi, 2007, Fuzzy C-Means Untuk Clustering Data Performance Mengajar Dosen, Proceeding pada 


\author{
seminar Nasional Teknologi di \\ Yogyakarta, STMIK AMIKOM, \\ Yogyakarta.
}

[3] Feddy setio Pribadi 2009, Pengklasifikasian siswa berdasarakan prestasi belajar dengan menggunakan logika Fuzzy clustering, Teknik Elektro FT UNNES .

[4] Noor Fitriana Hastuti 2010, Pemanfaatan Metode K-Means Clustering dalam Penentuan Penerima Beasiswa, Jurusan Informatika. Fakultas MIPA. Universitas Sebelas Maret.

[5] Prabowo Pudjo Widodo, Rahmadya Trios Handayanto, Herlawati 2013, Penerapan Data Mining dengan Matlab. Penerbit Rekayasa Sains, Bandung.

[6] Kusumadewi, S., Purnomo, H., 2010, Aplikasi Fuzzy Untuk Pendukung Keputusan, Graha Ilmu, Jakart.

[7] Kusrini, 2006, Algoritma Data Mining, Penerbit ANDI, Yogyakarta. 